\title{
Erythema Gyratum Repens with Esophageal Carcinoma
}

\author{
Langner $\mathrm{D}^{1}$, Wollschläger $\mathrm{S}^{2}$, Schönlebe $\mathbf{J}^{3}$, Wollina $\mathbf{U}^{1 *}$ \\ ${ }^{1}$ Department of Dermatology and Allergology \\ ${ }^{2}$ Department of Internal Medicine III \\ ${ }^{3}$ Institute for Pathology “Georg Schmorl“ Academic Teaching Hospital Dresden-Friedrichstadt, Städtisches Klinikum, Dresden, Germany
}

Received: July 11, 2016; Accepted: July 17, 2016; Published: July 22, 2016

*Corresponding author: Prof. Dr. U Wollina, Department of Dermatology and Allergology, Academic Teaching Hospital Dresden-Friedrichstadt, Friedrichstrasse 41, 01067 Dresden, Germany. E-mail: wollina-uw@khdf.de

\begin{abstract}
Erythema gyratum repens represents a rare facultative paraneoplasia. Quite often the dermatosis precedes tumor diagnosis. We report a 76-year-old male patient who initially presented with non-characteristic erythematous papules. After the diagnosis of an adenocarcinoma of the lower third of the esophagus the morphology of the dermatoses transformed into typically figurated erythemas with pronounced margins. Our case might support the hypothesis of cutaneous inflammation induced by crystallization of glutamine compounds in the skin. Tumor therapy was palliative by radiation. The erythema responded to a combined approach using topical corticosteroids and PUVA.
\end{abstract}

Keywords: Erythema Gyratum Repens; Paraneoplasia; Esophageal Carcinoma

\section{Introduction}

The first description of Erythema gyratum repens was made by Gammel who observed this rare skin disease in 1952 in a 55-year-old female with metastatic adenocarcinoma of the breast. Two days after mastectomie and axillary lymph node dissection erythema gradually disappeared. Six weeks later a complete remission was achieved [1].

In the majority of cases erythema gyratum repens is associated with a malignant tumor and represents a paraneoplastic dermatosis. The most common malignancy is lung cancer (32\%), followed by esophageal cancer (8\%) and breast cancer $(6 \%)$ $[2,3]$.

The current concept of pathophysiology assumes a tumorinduced humoral and/ or cellular immune response resulting in a cross-reactivity to skin or deposition of tumor antigen-antibody immunocomplexes along the basement membrane [2].

The typical clinical presentation is that of annular, garland shaped or spiral shaped erythemas with elevated borders, slight infiltration and scaling also known as wood grain pattern. The speed of propoagation reaches up to $10 \mathrm{~cm}$ per day [1].

Clinical presentation, however, may vary. About one third of patients do no suffer from malignant tumors, what fullfills the criterion of a facultative paraneoplastic dermatosis.

\section{Case Report}

\section{Medical history}

A 76-year-old male patient presented with pruritic and prgressive cutaneous lesions localized mainly of his trunk. The differential diagnoses at this time included eosinophilic dermatosis or systemic mastocytosis due to peripheral blood hypereosinophilia. He reported that 6 years and 6 months before similar lesions developed, that responded to psoralen Plus UltraViolett (UV)-Irradiation (PUVA) and topical corticosteroids.

During the last weeks, he expienrence an acute relapse associated with fatigue, loss of appetite, weightloss and pruitus.

Clinical investigations of internal organs were unremarkable. His skin, however, demonstrated multiple erythematous papules and plaques on trunk and proximal extremities. Darier sign was negative. During his stay in the hospital he developed target-like slightly elevated erythematous lesions (Fig. 1a, b).

A skin biopsy revealed an orthokeratotic epidermis with inclusions of serum and leukocytes and a psoriasisform pattern. In the central parts of the lesions spongiosis and parakeratosis was noted. There was a partly perivascular, partly interstitial inflammatory infiltrate composed of lymphocytes and monocytes, some neutrophilic and eosinophilic granulocytes, and occasional mast cells.Tere were no signs of a mycotic infection (Fig. 2).

Laboratory investigations: Hemoglobin $8.20 \mathrm{mmol} / \mathrm{l}(\downarrow)$, hematokrit $0.398 \mathrm{l} / \mathrm{l}(\downarrow)$, neutrophils $8.90 \mathrm{Gpt} / \mathrm{l}(\uparrow)$, eosinophils $0.70 \mathrm{Gpt} / \mathrm{l}(\uparrow)$, mast cell tryptase $22.1 \mu \mathrm{g} / \mathrm{l}(\uparrow)$. The other parameters were in the normal range.

Imaging: X-ray and computerized tomography demonstrated some mediastinal calcifiyed lymph nodes. Abdominal sonography and coloscopy were unremarkable. Gastroscopy demonstrated erosions and inflammatory lesions in the distal third of the esophagus and erosions on the antrum (Fig. 3). Under the suspicion of a Barrett syndrome (Differential diagnosis: erosive antrum gastritis) a biopsy was taken. Histologic investigations revealed a moderate differentiated adenocarcinoma of the esophagus on Barrett syndrome (Fig. 4a,b). 


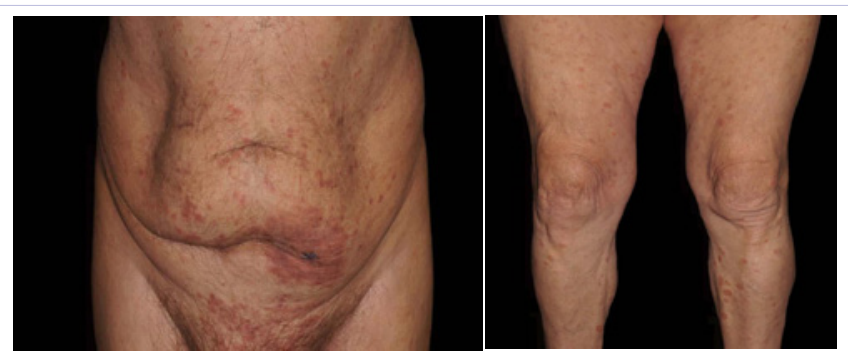

Figure 1: Clinical presentation of erythema gyratum repens. (a) Periumbilical figurated erythema. (b) On the legs erythematous plques with slightly elevated borders.

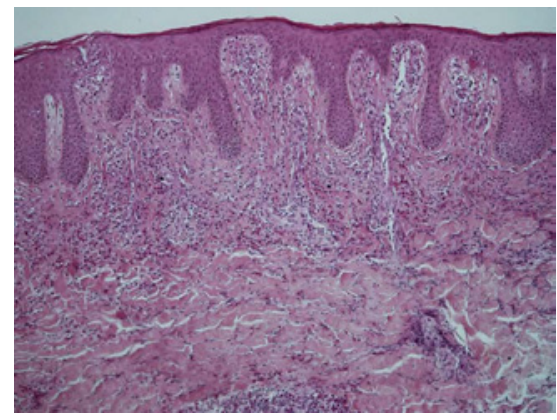

Figure 2: Histopathology of erythema gyratum repens with an inflammatory infiltrate in upper dermis and around skin appendages (HE x 10).

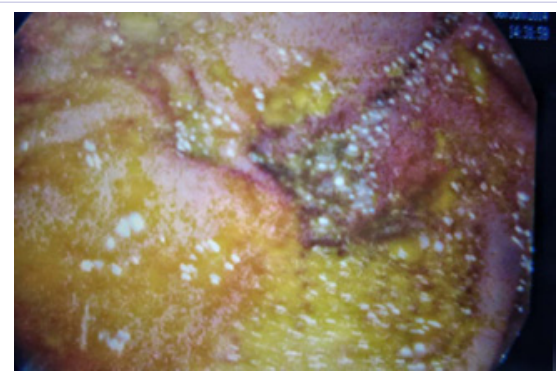

Figure 3: Endoscopy of distal esophagus with Barrett syndrome but without a primary tumor suspicion.

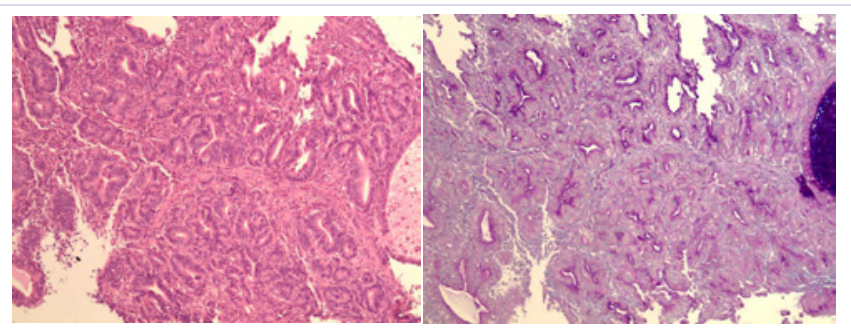

Figure 4: Histology of esophageal adenocarcinoma. (a) HE x 10; (b) PAS-stain (x10).

\section{Diagnosis}

Erythema gyratum repens associated with esophageal adenocarcinoma and Barrett syndrome (G2, category 4.3 of the modified Vienna classification [4].

\section{Therapy and course}

Topical treatment was realized using fluocinolone acetonid ointment twice daily in combination with bath-PUVA (8 sessions). Antipruritic oral treatment was realized by fexofenadin and ranitidin. This resulted in significant improvement of cutaneous lesions and complaints.

The cancer was treated by radiotherapy. Cutaneous lesions changed into wood grain pattern erythema but disappeared step by step thereafter.

\section{Discussion}

In case of paraneoplastic erythema gyratum repens, skin lesions often develop several months before detection of cancer [5]. Differential diagnosis include erythema gyratum repens-like mycosis fungoides [6], paraneoplastic bullous üemphigoid [7] or erythema gyratum-like bullous lupus erythematosus [8]. Other figurated erythemas also need consideration (Table 1).

Our case is remarkable because of initially unspecific cutaneous lesions. After the diagnosis of esophageal adenocarcinoma the lesions shape-shifted into the characteristic wood grain pattern. The case illustrates that erythema gyratum repends may develop from nonspecific cutaneous erythemas.

The etiology of erythema gyratum repens remains unclear. Recently, Forrester discussed a possible relationsship to L-glutamine cristallization in living tissues. Glutamine is released

\begin{tabular}{|c|c|}
\hline \multicolumn{2}{|l|}{ Table 1: } \\
\hline Disease & Remarks \\
\hline Bullous pemphigoid & rare manifestation, $\mathrm{BP}$-antibodies \\
\hline Dermatitis herpetiformis Duhring & $\begin{array}{l}\text { antibodies to endomysium and } \\
\text { transglutaminase }\end{array}$ \\
\hline Erythema annulare centrifugum & $\begin{array}{l}\text { association to allergy, infections, } \\
\text { tumors }\end{array}$ \\
\hline Eosinophilic annular erythema & subtype of Wells syndrome \\
\hline Erythema chronicum migrans & Borelliosis \\
\hline Erythema gyratum repens & facultative paraneoplasia \\
\hline $\begin{array}{l}\text { Erythema papulosa semicircularis } \\
\text { recidivans }\end{array}$ & $\begin{array}{l}\text { acute phases during hot summer } \\
\text { time, } \\
\text { unknown etiology }\end{array}$ \\
\hline Erythrokeratodermia variabilis & $\begin{array}{l}\text { genodermatosis, disorder of } \\
\text { keratinization }\end{array}$ \\
\hline Granuloma annulare & $\begin{array}{l}\text { histopathology with dermalen } \\
\text { granulomas }\end{array}$ \\
\hline IgA-lineäre Dermatose & $\begin{array}{l}\text { rarely figurate erythemas, } \\
\text { akantholysis }\end{array}$ \\
\hline Lupus gyratum repens & rare Lupus erythematosus variant \\
\hline Neutrophilic figurated erythema & $\begin{array}{l}\text { may be associated with leukemia/ } \\
\text { lymphoma of childhood }\end{array}$ \\
\hline Psoriasis & rarely with figurated erythemas \\
\hline Sweet-Syndrom & $\begin{array}{l}\text { figurated erythemas possible, } \\
\text { neutrophilic } \\
\text { dermatosis }\end{array}$ \\
\hline Urticaria & may show with elevated borders \\
\hline
\end{tabular}


by tumor cells. Self-assembled multi-ring formationsof these compounds in aqueous solutions resemble formally the shape of skin lesions in erythema gyratum repens [9]. Based on this hypothesis, the initial uncharactersitc skin lesions may be a results of low concentrations of glutamin in tissue. Only after clinical manifestation of cancer typical wood grain like lesions developed.

Due to the gae of the patient palliative tumor management by radiotherapy was an option. Cumulative doses of 50-70 Gy ensure 5-year-survival rates of $23 \%$. Tumors of the upper third of the esophagus have a better outcome with a 5-year survival rate of $44.5 \%$ [10].

\section{Summary and Conclusions}

Erythema gyratum repens is a rare facultative cutaneous paraneoplasia. Initial symptoms can be uncharacteristic, wood grain pattern lesions develop only in mature stages. In about $1 / 3$ of cases the disease is not tumor-associated. Nevertheless, a diagnosis of erythema gyratum repens warrants an in depth search for possible underlying malignancies.

\section{References}

1. Gammel JA. Erythema gyratum repens; skin manifestations in patient with carcinoma of breast. AMA Arch Derm Syphilol. 1952;66(4):494505.

2. Silva JA, Mesquita Kde C, Igreja AC, Lucas IC, Freitas AF, Oliveira SM, et al. Paraneoplastic cutaneous manifestations: concepts and updates. An Bras Dermatol. 2013;88(1):9-22.
3. Rongioletti F, Fausti V, Parodi A. Erythema gyratum repens is not an obligate paraneoplastic disease, a systemic review of the literature and personal knowledge. J Eur Acad Dermatol Venerol. 2014;28(1):112115. doi: 10.1111/j.1468-3083.2012.04663.x.

4. Stolte M. Die neue "Wien-Klassifikation" der epithelialen Neoplasien des Gastrointestinaltraktes. Pro oder Kontra? Pathologe. 2015;22(1):4-12.

5. Ramos-E-Silva M, Carvalho JC, Carneiro SC. Cutaneous paraneoplasia. Clin Dermatol. 2011;29(5):541-547. doi: 10.1016/j. clindermatol.2010.09.022

6. Nagase K, Shirai R, Okawa T, Inoue T, Misago N, Narisawa Y. CD4/CD8 double-negative mycosis fungoides mimicking erythema gyratum repens in a patient with underlying lung cancer. Acta Derm Venereol. 2014;94(1):89-90. doi: 10.2340/00015555-1618

7. Hauschild A, Swensson O, Christophers E. Paraneoplastic bullous pemphigoid resembling erythema gyratum repens. Br J Dermatol. 1999;140(3):550-552.

8. Fruchter R, Shaikh G, Myers KL, Eungdamrong NJ, Lee HS, Franks AG Jr. An erythema gyratum repens variant of bullous lupus erythematosus. JAAD Case Rep. 2016;2(2):111-113. doi: 10.1016/j.jdcr.2016.01.009

9. Forrester DM. Self-assembled multi-ring formations of glutamine and a possible link to erythema gyratum repens. Med Hypotheses. 2015;85(1):10-16. doi: 10.1016/j.mehy.2015.03.012

10. Chen DF, Yang ZY, Yin WB. Radiotherapy of 180 cases of operable esophageal carcinoma. World J Gastroenterol 1997;3(2):123-126. doi: 10.3748/wjg.v3.i2.123. 